\title{
Iron containing soil conditioner can effectively reduce cadmium and plumbum pollution in vegetable and soil
}

\author{
HUANG Dong-feng ${ }^{1, ~ a, ~ Z h a n g ~ Z a n-d e, ~}{ }^{2, b}$,Yang Zhong-fa ${ }^{3, c}$, LUO Tao ${ }^{1, d}$ \\ ${ }^{1}$ Institute of Soil and Fertilizer, Fujian Academy of Agricultural Sciences, Fuzhou ,Fujian, 350013, \\ China
}

2Datian county farmland construction and Soil Improvement Technology Promotion Station,Sanmin, Fujian,366100

${ }^{3}$ Good breed breeding ground in Xinluo District of Longyan,Fujian,364000

Aemail:huangdf@189.cn, bemail:512798033@qq.com, cemail:273544989@qq.com, ${ }^{\mathrm{d}}$ email:luotaofjfz@188.com

Keywords: Zero-valent iron powder, Soil conditioner, Vegetable, Soil, Heavy metal, Contamination of Cadmium (Cd) and Plumbum (Pb).

Abstract. Some kinds of compound soil conditioners (i.e., $\mathrm{Fe}_{1}, \mathrm{Fe}_{2}, \mathrm{Fe}_{3}$ and $\mathrm{Fe}_{4}$ ) were made from materials including zero-valent iron, sulfur and calcium hydroxide according to a certain weight proportion of them. And a soil-pot trial was conducted to test effects of using those soil conditioners on vegetable yield, contents of cadmium and plumbum in vegetable, and the available contents of cadmium and plumbum in soils. Results indicated that, applying those soil conditioners could increase vegetable's yield, and decrease the contents of cadmium and plumbum in vegetables, enhance soil's $\mathrm{pH}$, but reduce the available contents of $\mathrm{Cd}$ and $\mathrm{Pb}$ in soils to a certain extent. Among them, the effects of treatment "PS $+\mathrm{CF}+\mathrm{Fe}_{4}$ " were relatively the best, it could increase vegetable's yield by $48.54 \%$, decrease the contents of cadmium and plumbum in vegetables by $51.15 \% \sim 71.31 \%$ and $10.63 \% \sim 68.68 \%$, respectively, and enhance soil's $\mathrm{pH}$ by $42.03 \%$, but reduce the available contents of $\mathrm{Cd}$ and $\mathrm{Pb}$ in soils by $18.01 \%$ and $41.04 \%$, respectively.Consequently, this kind of soil conditioner $\left(\mathrm{Fe}_{4}\right)$ has a good application prospect in the field of soils, which were suffered from the contaminated by heavy metals $\mathrm{Cd}$ or $\mathrm{Pb}$.

\section{Introduction}

The heavy metal pollution of farmland soil in China is not optimistic. According to the "National soil pollution Survey Bulletin" ${ }^{[1]}$, the rate of soil spot pollution exceeding the standard in China is $19.4 \%$, of which mild to moderate pollution points account for $94.3 \%$ of the total soil pollution levels, and the types of soil pollution throughout the country are cadmium, mercury, arsenic, copper, lead, chromium, zinc, eight kinds of heavy metals, such as nickel, account for $82.8 \%$ of the total. Due to the heavy metal pollution of farmland soil, the heavy metal pollution problem of agricultural products produced on the polluted farmland is becoming more and more serious. It has been reported that the heavy metals in Chinese vegetable soil are higher than those in the field ${ }^{[2]}$. Therefore, the heavy metal pollution of vegetable soil is more concerned by the government and the general public.

The remediation techniques by changing the forms of heavy metals in soil, reducing their migration ability and bioavailability are easy to operate by environmental workers because of their low cost and simple operation ${ }^{[3,4]}$. The effects of these techniques are fast and suitable for large area farmland pollution control, so it has been paid more and more attention

At present, the main passivator materials used for in situ passivation and remediation of soil heavy metals include: phosphorus containing materials, organic materials, calcium silicate, clay minerals, metal oxides, biochar and new materials. However, the activity of heavy metals passivated by reducing iron powder in situ is rarely reported. Due to the advantages of metal reductive iron, such as low cost, good reducibility and fast reaction rate ${ }^{[5]}$, since Gillllam and Hannesin proposed that iron scrap can be used for in situ remediation of groundwater contaminated by heavy metals, the 
application of metal zero-valent iron to the reduction of heavy metal pollutants in water has become a very active research field. At present, the research on the application of zero-valent iron as a remediation agent for environmental pollution is mainly focused on the reaction of heavy metals in water, including degradation mechanism, reaction kinetics and influencing factors, etc. However, there are few studies on passivation and remediation of soils or sediments contaminated by heavy metals ${ }^{[6,7]}$,especially in vegetable fields contaminated by heavy metals.

In this study, iron powder, sulfur and calcium hydroxide were used as the main materials to prepare several iron-containing heavy metal compound passivator products(i.e.,soil conditioners), and were applied to the in situ passivation and remediation of farmland soil contaminated by heavy metals. The effects of using those soil conditioners on vegetables' yield, content of $\mathrm{Cd}$ and $\mathrm{Pb}$ in vegetables and the available content of $\mathrm{Cd}$ and $\mathrm{Pb}$ in soils were studied by a soil-pot trial. The aim of this paper is to provide new heavy metal passivator materials for the treatment of heavy metal polluted farmland.

\section{Materials and Methods}

The experiment was set up in the simulation room of the Institute of Soil and Fertilizers, Fujian Academy of Agricultural Sciences. The test soil was collected from the Fujian Science and Observation Station for Arable Land Conservation of Xitou Village, Baisha Town, Minhou County, Fujian Province. The soil was unpolluted paddy soil, and the parent material was hilly red soil, and the soil type was Huangnitian. In order to study the decontamination effect of heavy metal detergency agents, artificial addition of exogenous heavy metals were used to prepare experimental soils contaminated by heavy metals. The level of heavy metal pollution was designed to the level of "Soil Environmental Quality Standard" (GB15618-1995) (ie, $\mathrm{Cd} \geq 1 \mathrm{mg} \cdot \mathrm{kg}^{-1}, \mathrm{~Pb} \geq 500 \mathrm{mg} \cdot \mathrm{kg}^{-1}$ ), among which $\mathrm{Cd}$ uses analytical reagent $\mathrm{Cd}\left(\mathrm{NO}_{3}\right)_{2} \cdot 4 \mathrm{H}_{2} \mathrm{O}, \mathrm{Pb}$ uses analytical reagent $\mathrm{Pb}\left(\mathrm{NO}_{3}\right)_{2}$.

Seven treatments were designed, namely: (1) Clean soil (without addition of exogenous heavy metals $\mathrm{Cd}$ and $\mathrm{Pb}$ ); (2) Contaminated soil (addition of exogenous heavy metals $\mathrm{Cd} 1 \mathrm{mg} \cdot \mathrm{kg}^{-1} \mathrm{soil}$, $\mathrm{Pb} 500 \mathrm{mg} \cdot \mathrm{kg}^{-1}$ soil, the same below); (3) Contaminated soil + Chemical fertilizer (N $180 \mathrm{~kg} \cdot \mathrm{hm}^{-2}$ for each vegetable, and $\mathrm{P}_{2} \mathrm{O}_{5} 72 \mathrm{~kg} \cdot \mathrm{hm}^{-2}, \mathrm{~K}_{2} \mathrm{O} 90 \mathrm{~kg} \cdot \mathrm{hm}^{-2}$, the same applies hereinafter); (4) Contaminated soil + Chemical fertilizer + Iron-containing soil conditioner $1\left(450 \mathrm{~kg} \cdot \mathrm{hm}^{-2}\right.$ per stubble vegetable); (5) Chemical fertilizer + Iron-containing soil conditioner $2\left(480 \mathrm{~kg} \cdot \mathrm{hm}^{-2}\right.$ per stubble vegetable ); (6) Contaminated soil + Chemical fertilizer + Iron-containing soil conditioner 3 (each vegetable $1950 \mathrm{~kg} \cdot \mathrm{hm}^{-2}$ ); (7) Chemical fertilizer + Iron-containing soil conditioner 4 (1980 $\mathrm{kg} \cdot \mathrm{hm}^{-2}$ per stubble vegetable). They are represented by seven codes, i.e.: CS, PS, PS+CF, $\mathrm{PS}+\mathrm{CF}+\mathrm{Fe}_{1}, \mathrm{PS}+\mathrm{CF}+\mathrm{Fe}_{2}, \mathrm{PS}+\mathrm{CF}+\mathrm{Fe}_{3}$ and $\mathrm{PS}+\mathrm{CF}+\mathrm{Fe}_{4} . \mathrm{Each}$ treatment was repeated 3 times. The chemical fertilizers and iron-containing soil conditioners used for each treatment were mixed well with the soil samples before sowing. The first vegetable was Chinese cabbage (Brassica campestris L. ssp., Qingjiang cabbage), and the second crop was a spinach (Ipomoea aquatica Forsk, Thailand double axe).

The basic physicochemical properties of soil were determined by routine analysis of soil agrochemical methods ${ }^{[8]}$ and the available heavy metals $\mathrm{Cd}$ and $\mathrm{Pb}$ in soil were determined by DTPA extraction-atomic absorption spectrophotometry ${ }^{[9]}$.Test data processing using Microsoft Excel-2003 office software, statistical analysis using SPSS11.0 statistical software.

\section{Results and Analysis}

\section{Effects of applying iron-containing compound soil conditioners on the biological productivity of vegetables.}

Results (Table 1) showed that on the basis of conventional chemical fertilizer treatment of polluted soil, adding soil conditioners (i.e.,PS $+\mathrm{CF}+\mathrm{Fe}_{1}, \mathrm{PS}+\mathrm{CF}+\mathrm{Fe}_{2}, \mathrm{PS}+\mathrm{CF}+\mathrm{Fe}_{3}$ and $\mathrm{PS}+\mathrm{CF}+\mathrm{Fe}_{4}$ ) could increase the yield of vegetables to a certain extent.Compared with the PS $+\mathrm{CF}$ treatment, the yield of the first stubble and second stubble vegetables increased by $3.43 \% \sim 33.54 \%$ and 
$4.39 \% \sim 187.19 \%$ respectively. The average increase of the total yield of the two vegetables was $3.56 \% \sim 54.72 \%$. And the yields of vegetables produced by $\mathrm{PS}+\mathrm{CF}+\mathrm{Fe}_{3}$ and $\mathrm{PS}+\mathrm{CF}+\mathrm{Fe}_{4}$ were higher, and the total yield of the 2 strubbles of vegetable reached at $631.28 \mathrm{~g} \cdot \operatorname{pot}^{-1}$ and $606.07 \mathrm{~g} \cdot \operatorname{pot}^{-1}$, respectively. The results of variance analysis showed that the effects of $\mathrm{PS}+\mathrm{CF}+\mathrm{Fe}_{3}$ treatment on the increase of total yield of two crops of vegetables were very significantly $(P<0.01)$ better than those treatments of $\mathrm{PS}+\mathrm{CF}+\mathrm{Fe}_{2}, \mathrm{PS}+\mathrm{CF}+\mathrm{Fe}_{1}, \mathrm{PS}+\mathrm{CF}$, PS and $\mathrm{CS}$, etc. But there was no significant $(P>0.05)$ difference between $\mathrm{PS}+\mathrm{CF}+\mathrm{Fe}_{4}$. $\mathrm{PS}+\mathrm{CF}+\mathrm{Fe}_{4}$ treatment was also significantly superior $(P<0.01)$ to the treatments of $\mathrm{PS}+\mathrm{CF}+\mathrm{Fe}_{1}, \mathrm{PS}+\mathrm{CF}$, PS and $\mathrm{CS}$, and superior $(P<0.05)$ to $\mathrm{PS}+\mathrm{CF}+\mathrm{Fe}_{2}$. And $\mathrm{PS}+\mathrm{CF}+\mathrm{Fe}_{2}$ was significantly $(P<0.05)$ better than $\mathrm{PS}$, but it was no significant difference between treatments of $\mathrm{PS}+\mathrm{CF}+\mathrm{Fe}_{1}, \mathrm{PS}+\mathrm{CF}$ and $\mathrm{CS}$.

Tab.1 Effect of applying iron-containing soil conditioners on vegetable fresh yield

\begin{tabular}{|c|c|c|c|c|c|c|c|c|c|}
\hline \multirow[b]{2}{*}{ Treatment } & \multicolumn{3}{|c|}{ Brassica campestris L. ssp. } & \multicolumn{3}{|c|}{ Ipomoea aquatica Forsk } & \multicolumn{3}{|c|}{ Total } \\
\hline & $\begin{array}{l}\text { Yield } \\
/\left(\mathrm{g} \cdot \text { pot }^{-1}\right)\end{array}$ & $\begin{array}{c}\text { Comparison } \\
/ \%\end{array}$ & $\begin{array}{c}\text { Comparison } \\
/ \%\end{array}$ & $\begin{array}{l}\text { Yield } \\
/\left(\mathrm{g} \cdot \text { pot }^{-1}\right)\end{array}$ & $\begin{array}{c}\text { Comparison } \\
/ \%\end{array}$ & $\begin{array}{c}\text { Comparison } \\
/ \%\end{array}$ & $\begin{array}{c}\text { Yield } \\
/\left(\mathrm{g} \cdot \mathrm{pot}^{-1}\right)\end{array}$ & $\begin{array}{c}\text { Comparison } \\
/ \%\end{array}$ & $\begin{array}{c}\text { Comparison } \\
/ \%\end{array}$ \\
\hline CS & 296.67Bde & 8.74 & -15.16 & $81.41 \mathrm{Bbcd}$ & 59.45 & 39.53 & $378.08 \mathrm{Dcd}$ & 16.74 & -7.34 \\
\hline PS & $272.82 \mathrm{Be}$ & 1 & -21.98 & $51.06 \mathrm{Be}$ & 1 & -12.49 & 323.88Dd & 1 & -20.62 \\
\hline $\mathrm{PS}+\mathrm{CF}$ & $349.66 \mathrm{ABcde}$ & 28.17 & 1 & 58.35Bde & 14.28 & 1 & 408.01CDcd & 25.98 & 1 \\
\hline $\mathrm{PS}+\mathrm{CF}+\mathrm{Fe}_{1}$ & 361.66ABcde & 32.56 & 3.43 & $60.91 \mathrm{Bcde}$ & 19.29 & 4.39 & 422.56CDcd & 30.47 & 3.56 \\
\hline $\mathrm{PS}+\mathrm{CF}+\mathrm{Fe}_{2}$ & $380.91 \mathrm{ABabcd}$ & 39.62 & 8.94 & $90.34 \mathrm{Bb}$ & 76.93 & 54.82 & 471.25BCDbc & 45.5 & 15.5 \\
\hline $\mathrm{PS}+\mathrm{CF}+\mathrm{Fe}_{3}$ & $466.95 \mathrm{Aab}$ & 71.16 & 33.54 & $164.33 \mathrm{Aa}$ & 221.84 & 181.63 & $631.28 \mathrm{Aa}$ & 94.91 & 54.72 \\
\hline $\mathrm{PS}+\mathrm{CF}+\mathrm{Fe}_{4}$ & 438.49Aabc & 60.73 & 25.4 & $167.57 \mathrm{Aa}$ & 228.19 & 187.19 & $606.07 \mathrm{ABa}$ & 87.13 & 48.54 \\
\hline
\end{tabular}

Note: Different capital or small letters after data in the same column stand for very significant difference $(P<0.01)$ or significant difference $(P<0.05)$ in above table, the same below.

Effect of applying iron-containing soil conditioners on the contents of $\mathbf{C d}$ and $\mathrm{Pb}$ in vegetables

Results (Table 2) showed that, on the basis of conventional chemical fertilizer treatment of contaminated soil(PS+CF), the application of iron-containing soil conditioners (i.e., $\mathrm{PS}+\mathrm{CF}+\mathrm{Fe}_{1}, \mathrm{PS}+\mathrm{CF}+\mathrm{Fe}_{2}, \mathrm{PS}+\mathrm{CF}+\mathrm{Fe}_{3}$ and $\left.\mathrm{PS}+\mathrm{CF}+\mathrm{Fe}_{4}\right)$ could reduce the heavy metal $\mathrm{Cd}$ and $\mathrm{Pb}$ contents in vegetables to a certain extent.Compared with $\mathrm{PS}+\mathrm{CF}$ treatment, the content of $\mathrm{Cd}$ in the first and second stubble vegetable was decreased by $6.92 \% \sim 71.31 \%$ and $18.75 \% \sim 57.6 \%$, respectively, and the $\mathrm{Pb}$ decreased by $0.1 \% \sim 10.63 \%$ and $3.81 \% \sim 68.68 \%$, respectively. The effects of $\mathrm{PS}+\mathrm{CF}+\mathrm{Fe}_{4}$ and $\mathrm{PS}+\mathrm{CF}+\mathrm{Fe}_{3}$ on the reduction of $\mathrm{Cd}$ content in vegetable were better than other treatments. The contents of $\mathrm{Cd}$ in the first and second vegetables were decreased by $71.31 \%$ and $51.15 \%, 57.6 \%$ and $46.31 \%$, respectively. While the effects of $\mathrm{PS}+\mathrm{CF}+\mathrm{Fe}_{4}$ on the reduction of $\mathrm{Pb}$ content in vegetable were relatively the best,and the contents of $\mathrm{Pb}$ in the first and second stubble vegetables were decreased by $10.63 \%$ and $68.68 \%$, respectively. However, the contents of $\mathrm{Cd}$ and $\mathrm{Pb}$ in vegetable were the highest in polluted soil without fertilization treatment(PS), and the lowest in clean soil without fertilization treatment(CS).

Tab.2 Effect of applying iron-containing soil conditioners on contents of cadmium and plumbum in vegetable

\begin{tabular}{|c|c|c|c|c|c|c|c|c|}
\hline \multirow{3}{*}{ Treatment } & \multicolumn{4}{|c|}{ Brassica campestris L. ssp. } & \multicolumn{4}{|c|}{ Ipomoea aquatica Forsk } \\
\hline & \multicolumn{2}{|c|}{$\mathrm{Cd}$} & \multicolumn{2}{|c|}{$\mathrm{Pb}$} & \multicolumn{2}{|c|}{$\mathrm{Cd}$} & \multicolumn{2}{|c|}{$\mathrm{Pb}$} \\
\hline & $\begin{array}{c}\text { Mass fraction } \\
\quad /\left(\mathrm{mg} \cdot \mathrm{kg}^{-1}\right)\end{array}$ & $\begin{array}{c}\text { Comparison } \\
/ \% \\
\end{array}$ & $\begin{array}{c}\text { Mass fraction } \\
/\left(\mathrm{mg} \cdot \mathrm{kg}^{-1}\right)\end{array}$ & $\begin{array}{c}\text { Comparison } \\
/ \% \\
\end{array}$ & $\begin{array}{c}\text { Mass fraction } \\
\quad /\left(\mathrm{mg}^{2} \cdot \mathrm{kg}^{-1}\right)\end{array}$ & $\begin{array}{c}\text { Comparison } \\
/ \%\end{array}$ & $\begin{array}{c}\text { Mass fraction } \\
/\left(\mathrm{mg} \cdot \mathrm{kg}^{-1}\right)\end{array}$ & $\begin{array}{c}\text { Comparison } \\
/ \% \\
\end{array}$ \\
\hline $\mathrm{CS}$ & $0.17 \mathrm{Ee}$ & -92.11 & $0.08 \mathrm{~B}$ & -95.65 & $0.07 \mathrm{Gf}$ & -93.50 & $0.24 \mathrm{De}$ & -95.76 \\
\hline PS & $2.13 \mathrm{Aa}$ & 0.20 & $2.12 \mathrm{Aa}$ & 13.94 & 1.09Aa & 8.14 & 6.14Aa & 6.73 \\
\hline $\mathrm{PS}+\mathrm{CF}$ & $2.13 \mathrm{Aa}$ & 1 & $1.86 \mathrm{Aa}$ & 1 & $1.01 \mathrm{ABa}$ & 1 & 5.75Aab & 1 \\
\hline $\mathrm{PS}+\mathrm{CF}+\mathrm{Fe}_{1}$ & $1.86 \mathrm{ABCa}$ & -12.49 & $1.74 \mathrm{Aa}$ & -6.18 & $0.82 \mathrm{BCb}$ & -18.75 & $5.53 \mathrm{ABab}$ & -3.81 \\
\hline $\mathrm{PS}+\mathrm{CF}+\mathrm{Fe}_{2}$ & $1.98 \mathrm{ABa}$ & -6.92 & $1.83 \mathrm{Aa}$ & -1.59 & $0.62 \mathrm{CDEc}$ & -38.71 & $4.88 \mathrm{Bc}$ & -15.14 \\
\hline $\mathrm{PS}+\mathrm{CF}+\mathrm{Fe}_{3}$ & $1.04 \mathrm{CDcd}$ & -51.15 & $1.86 \mathrm{Aa}$ & -0.10 & $0.54 \mathrm{Ecd}$ & -46.31 & $1.80 \mathrm{Cd}$ & -68.68 \\
\hline $\mathrm{PS}+\mathrm{CF}+\mathrm{Fe}_{4}$ & $0.61 \mathrm{DEde}$ & -71.31 & $1.66 \mathrm{Aa}$ & -10.63 & $0.43 \mathrm{EFd}$ & -57.60 & $1.82 \mathrm{Cd}$ & -68.37 \\
\hline
\end{tabular}

The results of variance analysis showed that $\mathrm{PS}+\mathrm{CF}+\mathrm{Fe}_{4}$ had the best effect on the reduction of $\mathrm{Cd}$ content of Brassica chinensis, which was very significantly $(P<0.01)$ better than $\mathrm{PS}, \mathrm{PS}+\mathrm{CF}$, 
$\mathrm{PS}+\mathrm{CF}+\mathrm{Fe}_{1}$ and $\mathrm{PS}+\mathrm{CF}+\mathrm{Fe}_{2}$, but there was no significant difference between $\mathrm{PS}+\mathrm{CF}+\mathrm{Fe}_{3}$. And $\mathrm{PS}+\mathrm{CF}+\mathrm{Fe}_{3}$ treatment was also very significantly better than PS and PS $+\mathrm{CF}$, and significantly superior $(P<0.05)$ to $\mathrm{PS}+\mathrm{CF}+\mathrm{Fe}_{1}$ and $\mathrm{PS}+\mathrm{CF}+\mathrm{Fe}_{2}$ treatment. In addition to the Clean soil treatment(CS), there was no significant difference between other treatments except for the reduction of heavy metal $\mathrm{Pb}$ content in pakchoi (Brassica campestris L.). The effects of $\mathrm{PS}+\mathrm{CF}+\mathrm{Fe}_{4}$ treatment on reducing $\mathrm{Cd}$ content of water spinach were very significantly better than PS,PS $+\mathrm{CF}$ and $\mathrm{PS}+\mathrm{CF}+\mathrm{Fe}_{1}$ treatments, and significantly better than $\mathrm{PS}+\mathrm{CF}+\mathrm{Fe}_{2}$ treatment, but there was no significant difference between $\mathrm{PS}+\mathrm{CF}+\mathrm{Fe}_{3}$ treatment.The effects of $\mathrm{PS}+\mathrm{CF}+\mathrm{Fe}_{3}$ and $\mathrm{PS}+\mathrm{CF}+\mathrm{Fe}_{4}$ on the reduction of heavy metal $\mathrm{Pb}$ content were better than $\mathrm{PS}, \mathrm{PS}+\mathrm{CF}, \mathrm{PS}+\mathrm{CF}+\mathrm{Fe}_{1}$ and $\mathrm{PS}+\mathrm{CF}+\mathrm{Fe}_{2}$ treatments, but there was no significant difference between them. $\mathrm{PS}+\mathrm{CF}+\mathrm{Fe}_{2}$ treatment was also very significantly better than PS and PS $+\mathrm{CF}$, and significantly better than $\mathrm{PS}+\mathrm{CF}+\mathrm{Fe}_{1}$.

\section{The effect of applying iron-containing soil conditioners on soil $\mathrm{pH}$ and available $\mathrm{Cd}, \mathrm{Pb}$ after harvest}

The results of potted soil sampling and analysis after planting two crops of vegetables (Table 3) showed that: on the basis of conventional application of chemical fertilizer to polluted soil (PS+CF), adding soil conditioners could improve the soil $\mathrm{pH}$ to a certain extent and increase the soil $\mathrm{pH}$ by $3.78 \% \sim 41.28 \%$, and decrease the contents of available $\mathrm{Cd}$ and $\mathrm{Pb}$ by $3.77 \% \sim 18.01 \%$ and $7.57 \% \sim 41.04 \%$, respectively. $\mathrm{PS}+\mathrm{CF}+\mathrm{Fe}_{4}$ treatment had the best effect on increasing soil $\mathrm{pH}$ and reducing soil available $\mathrm{Cd}$ and $\mathrm{Pb}$ contents. The results of variance analysis showed that the effect of $\mathrm{PS}+\mathrm{CF}+\mathrm{Fe}_{4}$ was very significantly $(P<0.01)$ better than that of $\mathrm{CS}, \mathrm{PS}, \mathrm{PS}+\mathrm{CF}, \mathrm{PS}+\mathrm{CF}+\mathrm{Fe}_{1}$ and $\mathrm{PS}+\mathrm{CF}+\mathrm{Fe}_{2}$, but the difference with $\mathrm{PS}+\mathrm{CF}+\mathrm{Fe}_{3}$ treatment was not significant. $\mathrm{PS}+\mathrm{CF}+\mathrm{Fe}_{3}$ treatment was also very significantly $(P<0.01)$ better than that of $\mathrm{CS}, \mathrm{PS}, \mathrm{PS}+\mathrm{CF}, \mathrm{PS}+\mathrm{CF}+\mathrm{Fe}_{1}$ and $\mathrm{PS}+\mathrm{CF}+\mathrm{Fe}_{2}$. The effect of clean soil treatment(CS) on the reduction of available Cd content in soil was significantly better than that of other treatments. The available $\mathrm{Cd}$ content in polluted soil (PS)was significantly higher than that in other treatments.Compared with PS $+\mathrm{CF}$ treatment, $\mathrm{PS}+\mathrm{CF}+\mathrm{Fe}_{4}$ treatment could very significantly reduce soil available $\mathrm{Cd}$ content, and $\mathrm{PS}+\mathrm{CF}+\mathrm{Fe}_{2}$ treatment could also significantly reduce that.The decrease of available $\mathrm{Pb}$ content in soil was the best in $\mathrm{PS}+\mathrm{CF}+\mathrm{Fe}_{4}$ treatment, which was very significantly $(P<0.01)$ better than that in $\mathrm{PS}+\mathrm{CF}+\mathrm{Fe}_{1}, \mathrm{PS}+\mathrm{CF}$ and $\mathrm{PS}$ treatment, but there was no significant difference between $\mathrm{PS}+\mathrm{CF}+\mathrm{Fe}_{2}$ and $\mathrm{PS}+\mathrm{CF}+\mathrm{Fe}_{3}$. The content of available $\mathrm{Pb}$ in clean soil (CS) was very significantly $(P<0.01)$ lower than that in other treatments.

Tab.3 Effect of applying iron-containing soil conditioners on $\mathrm{pH}$, contents of available cadmium and plumbum in soil after harvest of vegetables

\begin{tabular}{|c|c|c|c|c|c|c|c|c|c|}
\hline \multirow[b]{2}{*}{ Treatment } & \multicolumn{3}{|c|}{$\mathrm{pH}$} & \multicolumn{3}{|c|}{ Available Cd } & \multicolumn{3}{|c|}{ Available $\mathrm{Pb}$} \\
\hline & Value & $\begin{array}{c}\text { Comparison } \\
/ \%\end{array}$ & $\begin{array}{c}\text { Comparison } \\
/ \%\end{array}$ & $\begin{array}{l}\text { fraction } \\
/\left(\mathrm{mg} \cdot \mathrm{kg}^{-1}\right)\end{array}$ & $\begin{array}{c}\text { Comparison } \\
/ \%\end{array}$ & $\begin{array}{c}\text { Comparison } \\
/ \%\end{array}$ & $\begin{array}{c}\text { Mass fraction } \\
/\left(\mathrm{mg} \cdot \mathrm{kg}^{-1}\right)\end{array}$ & $\begin{array}{c}\text { Comparison } \\
/ \%\end{array}$ & $\begin{array}{c}\text { Comparison } \\
/ \%\end{array}$ \\
\hline $\mathrm{CS}$ & $4.14 \mathrm{Cc}$ & -6.54 & -6.05 & $0.01 \mathrm{De}$ & -99.42 & -99.29 & $1.63 \mathrm{Ee}$ & -99.47 & -99.45 \\
\hline PS & $4.43 \mathrm{BCc}$ & 1 & 0.53 & $0.95 \mathrm{Aa}$ & 1 & 22.59 & $307.55 \mathrm{Aa}$ & $\backslash$ & 3.65 \\
\hline $\mathrm{PS}+\mathrm{CF}$ & $4.41 \mathrm{Cc}$ & -0.53 & 1 & $0.77 \mathrm{Bb}$ & -18.43 & 1 & 296.71ABa & -3.52 & 1 \\
\hline $\mathrm{PS}+\mathrm{CF}+\mathrm{Fe}_{1}$ & $4.58 \mathrm{BCc}$ & 3.23 & 3.78 & $0.74 \mathrm{BCbc}$ & -21.50 & -3.77 & 274.25ABCab & -10.83 & -7.57 \\
\hline $\mathrm{PS}+\mathrm{CF}+\mathrm{Fe}_{2}$ & $4.75 \mathrm{BCc}$ & 7.07 & 7.63 & $0.68 \mathrm{BCcd}$ & -28.02 & -11.76 & 213.81CDcd & -30.48 & -27.94 \\
\hline $\mathrm{PS}+\mathrm{CF}+\mathrm{Fe}_{3}$ & 6.10Aab & 37.67 & 38.40 & $0.71 \mathrm{BCbcd}$ & -24.99 & -8.05 & 208.58CDcd & -32.18 & -29.70 \\
\hline $\mathrm{PS}+\mathrm{CF}+\mathrm{Fe}_{4}$ & $6.26 \mathrm{Aa}$ & 41.28 & 42.03 & $0.63 \mathrm{Cd}$ & -33.12 & -18.01 & 174.94Dd & -43.12 & -41.04 \\
\hline
\end{tabular}

\section{Discussions}

\section{Effect of using iron-containing soil conditioners on vegetable yield}

At present, there is no report on the application of iron-containing soil conditioner to the yield of vegetables grown on heavy metal contaminated vegetable fields. Our experimental results showed that: on the basis of conventional chemical fertilizer treatment of polluted soil, adding 
several iron-containing soil conditioners could increase the total yield of two crops of vegetables by $3.56 \% \sim 54.72 \%$, and the yields of vegetables treated with $\mathrm{PS}+\mathrm{CF}+\mathrm{Fe}_{3}$ and $\mathrm{PS}+\mathrm{CF}+\mathrm{Fe}_{4}$ were higher than other treatments. The vegetable yield of polluted soil without fertilization treatment was the lowest, and that of clean soil without fertilization treatment was lower. The addition of several iron-containing soil conditioners (i.e., $\mathrm{PS}+\mathrm{CF}+\mathrm{Fe}_{1}, \mathrm{PS}+\mathrm{CF}+\mathrm{Fe}_{2}, \mathrm{PS}+\mathrm{CF}+\mathrm{Fe}_{3}$ and $\mathrm{PS}+\mathrm{CF}+\mathrm{Fe}_{4}$ ) could increase the biological yield of vegetables to a certain extent, which was due to the fact that several soil conditioners could be used to form insoluble compounds with active cadmium and lead ions in soil, which to some extent reduce the content of available cadmium lead in the soil (see Table 3), thus alleviating to some extent the inhibition of excessive heavy metals in the soil on vegetable growth. It is beneficial to the increase of vegetable yield.

\section{Effect of using iron-containing soil conditioners on heavy metal content in vegetable-soil system}

At present, there are few reports on the treatment of heavy metal pollution in farmland soil by using iron-containing soil conditioner. The results showed that ferrous sulfate has obvious fixation effect in arsenic-contaminated soil. However, the soil acidification caused by it can not be ignored, it can release the fixed $\mathrm{Cd} 、 \mathrm{Cu} 、 \mathrm{Zn}$ in soil, and the $\mathrm{pH}$ change of soil must be controlled by the application of lime. Compared with $\mathrm{FeSO}_{4}$, the process of conversion of zero-valent Fe into oxide in soil is slower than that of $\mathrm{FeSO}_{4}$. However, the amount of oxides produced is relatively large, so the zero-valent $\mathrm{Fe}$ is preferable in the long-term stability of remediation effect, and it will not cause soil acidification $^{[10,11]}$. This is also verified by the results of this trial (see Table 3 ). In the study of using zero-valent iron to degrade the soil contaminated by Cr-VI, Franco and others ${ }^{[12]}$ used nano-iron particles to repair the contaminated soil. Through batch and semi-batch experiments, they were reduced and removed by using different kinds of metal iron with different treatment methods. Including $\mathrm{Fe}^{2+}$ (sulphate solution), zero-valent iron (metal scrap iron, non-stabilized zero-valence iron, colloidal zero-valence iron [through carboxymethyl cellulose) stabilization and ultrasonic action]. The results showed that the modified dispersed colloidal zero-valence iron was the best. Under the condition that the average mass concentration of $\mathrm{Cr}(\mathrm{VI})$ in soil was $(456 \pm 35) \mathrm{mg} \cdot \mathrm{kg}^{-1}, 1 \mathrm{~g}$ colloidal zero-valent iron could reduce $280 \mathrm{mg} \mathrm{Cr}(\mathrm{VI})$. This study indicates that the zero-valent iron technique is an effective method for remediation of $\mathrm{Cr}(\mathrm{VI})$ contaminated soil and sediment. $\mathrm{Li}$ Tianran, et al's results ${ }^{[13]}$ showed that the immobilization efficiency of iron powder on $\mathrm{V}$ and $\mathrm{Cr}$ in vanadium smelting slag contaminated soil was $99.6 \%$ and $78.5 \%$, respectively. In addition, some studies have shown that zero-valent iron can immobilize heavy metals in soils and sediments ${ }^{[14,15]}$. At present, the application of soil conditioner containing iron on vegetable ground has not been reported. Our results showed that on the basis of conventional chemical fertilizer treatment in polluted soil, the contents of $\mathrm{Cd}$ and $\mathrm{Pb}$ in vegetables could be reduced by adding soil conditioners (i.e., $\mathrm{PS}+\mathrm{CF}+\mathrm{Fe}_{1}, \mathrm{PS}+\mathrm{CF}+\mathrm{Fe}_{2}, \mathrm{PS}+\mathrm{CF}+\mathrm{Fe}_{3}$ and $\mathrm{PS}+\mathrm{CF}+\mathrm{Fe}_{4}$ ). And the contents of available $\mathrm{Cd}$ and $\mathrm{Pb}$ in soil were reduced, and the effects of $\mathrm{PS}+\mathrm{CF}+\mathrm{Fe}_{4}$ treatment on reducing the contents of heavy metal $\mathrm{Cd}$ and $\mathrm{Pb}$ in vegetables and the available $\mathrm{Cd}$ and $\mathrm{Pb}$ contents in soil were relatively best.

\section{Conclusion}

The results of this study showed that: on the basis of conventional chemical fertilizer treatment of polluted soil, the application of iron-containing soil conditioners could increase the yield of vegetables (pakchoi and water spinach) by 3.56\% 54.72\%, reduce the heavy metal Cd content of vegetables by $6.92 \% \sim 71.31 \%, \mathrm{~Pb} 0.10 \% \sim 68.68 \%$, and increase soil $\mathrm{pH}$ by $3.78 \sim 41.28$, decrease soil available $\mathrm{Cd} 3.77 \% \sim 18.01 \%$ and available $\mathrm{Pb} 7.57 \% \sim 41.04 \%$. Among them, the $\mathrm{PS}+\mathrm{CF}+\mathrm{Fe}_{4}$ treatment increased vegetable yield by $48.54 \%$, decreased vegetable's $\mathrm{Cd}$ by $51.15 \% \sim 71.31 \%$ and $\mathrm{Pb}$ by $10.63 \% \sim 68.68 \%$, increased soil $\mathrm{pH}$ value by $42.03 \%$, and decreased soil available $\mathrm{Cd}$ content in soil by $18.01 \%$ and $\mathrm{Pb}$ by $41.04 \%$, and the relative optimum passivation effect was obtained.

To sum up, the addition of "iron-containing soil conditioner 4" to soils polluted by heavy metal $\mathrm{Cd}$ and $\mathrm{Pb}$, not only increased the yield of vegetables, decreased the content of $\mathrm{Cd}$ and $\mathrm{Pb}$ in 
vegetables, but also significantly reduced the content of available $\mathrm{Cd}$ and $\mathrm{Pb}$ in soil. Therefore, this iron-containing soil conditioner has a certain prospect of popularization and application in farmland where the content of heavy metal $\mathrm{Cd}$ and $\mathrm{Pb}$ in soil exceeds the standard. However, the results of this experiment are only obtained from the greenhouse pot experiment and need to be further verified by field experiments.

\section{Acknowledgements}

This research was financially supported by National science and technology support program (2015BAD05B01-05),Fujian province belongs to the basic scientific research project of public welfare (2017R1022-1,2018R1022-4); The scientific and technological innovation team of the Fujian Academy of Agricultural Sciences (STIT2017-2-10); and The research center of Fujian provincial land cultivation engineering technology.

\section{References}

[1]Ministry of Environmental Protection, Ministry of Land and Resources. National soil pollution $\begin{array}{lllll}\text { Survey } & \text { Bulletin } & {[\mathrm{EB} / \mathrm{OL}]} & \text { April } & 17,\end{array}$ http://www.cenews.com.cn/sylm/jsxw/201404/t20140418_772973.htm.

[2] Pang Wenpin, Qin Faxin, Lu Yachao, et al. Chemical speciation and risk Assessment of heavy Metals in farmland soil of Xingren Coal Mine, Guizhou Province [J]. Journal of Applied Ecology, 2016,27(5):1468-1478

[3] Brown S, Chaney R, Hallfrisch J, et al. In situ soil treatments to reduce the phyto- and bioavailability of lead, zinc, and cadmium[J]. Environmental Quality, 2004,33(2): 522-531

[4]Li Jianrui, $\mathrm{Xu}$ Yingming, Lin Dasong, et al. Research progress on in situ passive remediation of heavy metal pollution in farmland [J]. Journal of eco-environment, 2014,23 (4): 721-728

[5]Wang Liqun, Luo Lei, Ma Yibing, et al. Advances in in situ Passivation and remediation of soils contaminated by heavy Metals [J]. Journal of Applied Ecology,2009,20(5):1214-1222

[6]Wang Yifei, Wu Junde, Deng Binglu. Inhibition effect and mechanism of apatite-zero valent iron on copper and lead release from sediment [J]. Journal of Environmental Sciences,2016,36(7):2533-2539

[7]Fu R,Yang Y,Xu Z, et a1. The removal of chromium(VI)and lead (II)from groundwater using sepiolite-supported nanoscale zero-valentiron(S-NZVI) [J]. Chemosphere, 2015,138:726-734

[8]Chief of Soil Society of China. Methods of soil agricultural chemistry analysis [M]. Beijing: China Agricultural Science and Technology Press, 2000.

[9] State Administration of quality supervision, Inspection and Quarantine of People's Republic of China, China National Standardization Administration Commission. GB/T 23739-2009 determination of soil quality available lead and cadmium by atomic absorption spectrometry [S].2009-11-01

[10]Hartley W, Edwards R, Leppn W. Arsenic and heavy metal mobility in iron oxide-amended contaminated soils as evaluated by short- and long-term leaching tests[J]. Environmental Pollution, 2004,131:495-504

[11]Kumpiene J, Lagerkvist A, Maurice C. Stabilization of $\mathrm{As}, \mathrm{Cr}, \mathrm{Cu}, \mathrm{Pb}$ and $\mathrm{Zn}$ in soil using amendments-a review[J]. Waste Management,2008,28: 215-225

[12]Franco D V, Silval L M D, Jardim W F. Reduction of hexavalent chromium in soil and ground water using zero-valent iron under batch and semi-batch conditions[J]. Water Air\&Soil Pollution, 2009,197(1-4):49-60

[13]Li Tianran, Jiang Jianguo, Li Dean, et al. Solidification effect of iron-based solid materials on vanadium contaminated soil [J]. Chinese Environmental Science, 2016,36 (7): 2108-2114 
[14]Wu Baolin, Yang Zhihui, Chai Liyuan, et al. Remediation effect of Phosphorus-based and Iron-based Phosphoryl Phosphorimide and Iron based Phosphoryl Phosphorimide on soil polluted by Pb, Cdand As[J]. Journal of Safety and Environment, 2015,15(5):314-319

[15]Tomasevic D D, Kozma G, Kerkez D V, et a1. Toxic metal immobilization in contaminated sediment using bentonite and kaolinite-supported nano zero-valent iron[J]. Journal of Nanoparticle Research,2014,16(8):1-15 